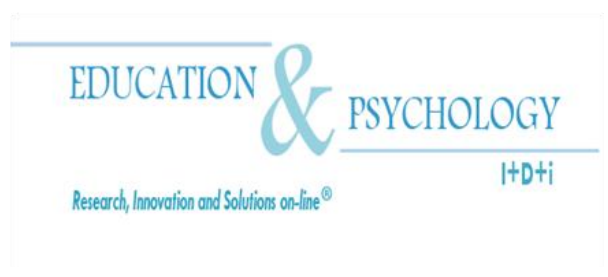

\title{
Methodology and Resources of the Itinerant Speech and Hearing Teacher
}

\section{José J. Carrión-Martínez \& Antonio Luque de la Rosa}

Departamento de Educación, Universidad de Almería

Spain

Correspondence: José Juan Carrión-Martínez. Universidad de Almería, Carretera de Sacramento s/n, 04120, La Cañada de San Urbano (ALMERÍA) E-mail: jcarrion@ual.es

(C) Education \& Psychology I+D+i and Editorial EOS (Spain) 


\section{Abstract}

Introduction. Having spent twenty years of business and professional development from the emergence of speech and hearing teacher traveling, it seems appropriate to reflect on the role he has been playing this figure in order to apprehend the things considered to improve the approach to adopt towards to promote the quality of its educational activities. This study aims to contribute to the understanding of the educational work of these professionals doing a tour of the methodological approaches that support it, while analyzing the organization and teaching strategies that perform and the types of resources and materials used.

Method. The object-problem of this study will conduct an analysis of the situation faced by mobile professionals for hearing and speech and deepen the study of the methodology and resources that characterize the action being carried out. The research now presented is within the ambit interpretive approach or paradigm, and that the nature of the offense under investigation, for the very purpose of the research activity, for how to address the analysis and interpretation of data and qualitative methodology from which we use for making information.

Results. The results show that the methodology developed by teachers of speech and hearing itinerant has a high penetration of clinical intervention models and therapeutic, with a strong presence of activities and resources focused on fonoarticulatorios components.

Discussion and conclusions. The main focus of its activities are focused on reproductiverepetitive procedures in which the predominant action of the teacher, not working the contents of other areas or activities are generally assigned to regular classrooms.

Keywords. Teacher, speech, school organization, resources, disability.

Received: 04/25/13 Initial aceptance: 06/23/13 Final aceptance: 07/15/13 


\section{Metodología y Recursos del Maestro Itinerante de Audición y Lenguaje}

\section{Resumen}

Introducción. Habiendo transcurrido veinte años de andadura y desarrollo profesional desde el surgimiento del maestro de audición y lenguaje itinerante, parece conveniente reflexionar sobre el papel que ha venido desempeñando esta figura con objeto de aprehender las consideraciones oportunas que mejoren los planteamientos a adoptar de cara a promover la calidad de su actuación educativa. Con este estudio se pretende contribuir a la comprensión de la acción educativa de estos profesionales realizando un recorrido por los planteamientos metodológicos que la fundamentan, al tiempo que se analizan las estrategias organizativas y didácticas que llevan a cabo así como la tipología de recursos y materiales que utilizan.

Método. El objeto-problema de este estudio consistirá en realizar un análisis de la situación que viven los profesionales itinerantes de audición y lenguaje, profundizando en el estudio de la metodología y recursos que caracterizan la acción que vienen desarrollando. La investigación se ha llevado a cabo con una aproximación cualitativa a la acción de nueve maestros itinerantes de audición y lenguaje, repartidos en diferentes áreas geográficas. Dado el enfoque, el instrumento de toma de información prioritario ha sido la entrevista en profundidad, llevadas a cabo con una inmersión de campo de un año de duración. El análisis de los datos se ha desarrollado con estrategias de reducción, depuración, precategorización y categorización.

Resultados. Los resultados ponen de manifiesto que la metodología que desarrollan los maestros de audición y lenguaje itinerantes presenta una gran penetración de los modelos de intervención clínico-terapéuticos, con fuerte presencia de actividades y recursos focalizados en los componentes fonoarticulatorios.

Discusión y conclusiones. El eje principal de su actuación se centra en procedimientos reproductivos-repetitivos en los que predomina la actuación del docente; no se trabajan los contenidos del resto de las áreas ni se suelen encargar actuaciones para el aula ordinaria.

Palabras clave: Maestro, lenguaje, organización escolar, recursos, discapacidad. 


\section{Introduction}

Language and hearing are two concepts whose meanings and interrelationship can only be understood in the context of the broader term of communication. As defined by Dubois (1991), communication is "the very essence of our experience in the world and of the world in us: Communicating above all is to feel understood and appreciated. It is imagining that the other responds to us" (p. 46). Human beings communicate between themselves through different means and systems: gestures, music, artistic representations, numeric and graphic symbols. Communication plays a more important role in our day than ever before, and thanks to progress in technology, it adopts forms and aspects that in former times were never dreamed of. This development has brought with it new difficulties, not only in the study of communication itself, but also, in a particular way, in the study of our principal means of comunication: language (Wigg, 2001).

Language is vitally important not only because of its communicative, expressive function, but also because of its extremely important role in elaborating thought (Crystal, 1981; Monfort, 1983, 1990; Vigotsky, 1995). The development of intelligence, and by extension, of human personality, is dependent on the language that acts as a vehicle for the complex web of abstractions that is formed in our brain (Cooper, Moodley \& Reynell, 1982). While in our country there have long been professionals dedicated to the specific treatment of pronunciation and speech problems (speech therapists), in the 1990s a new teaching professional emerged: the language and hearing teacher (hereafter, LH).

The desire for a change in role can be seen in the name itself, moving beyond the idea of therapeutic recovery and rehabilitation in certain channels of communication (hearing/phonation), towards a concept of a professional who furthers communicative, cognitive and socio-personal development, across the student community, through language.

\section{Existing models: the multidimensional perspective}

Different classification systems can be applied to the options for intervention, where different parameters and criteria are taken into consideration. Gallardo-Ruiz and GallegoOrtega (1993) initially point to four models of intervention in the linguistic-communication facet:

a) Linguistic model. This model looks for an independent linguistic disability that must be assessed and treated from a linguistic perspective. From this view, there is a 
distinction between the formal approach (concerned with establishing syntactic structures, semantic relations and phonological contrasts) and another more functional approach (a more pragmatic perspective in natural settings).

b) Behavioral model. The intervention addresses a certain behavior, applying the sample principles of psychology as with other behaviors.

c) Cognitive model. This model defends the existence of a close relationship between thought and language.

d) Clinical model. Psychoanalytical therapies are applied in order to intervene in the symptoms and etiology of the disabilities.

We find that models that are more or less biomedical (causes) or behavioral (symptoms) (Bloom \& Lahey, 1978) are focusing on one facet of the problem. In contrast, today's multidimensional, ecological view of the educational act, of human beings, and of language and hearing teachers leads us to opt for an eclectic model as the most suitable for addressing language development in the school setting. Such a model is inspired by sociointeractive theories that accept diversity as the starting point, and its main objective is global language development (Lindsay \& Dockrell, 2002; Castejón-Fernández \& España-Ganzaráin, 2004; Acosta-Rodríguez, 2005, 2006a). The concept of curriculum support is fundamental, so that intervention addresses not only the pupil who presents the disability, but also other points within the educational community (Prelock, 2000; Lindsay \& Dockrell, 2002; CastejónFernández \& España-Ganzaráin, 2004; Acosta-Rodríguez, 2005, 2006b).

This comprehensive model takes treatment functionality as its criterion, having a global, wholistic thrust that selects the most helpful approaches for guiding a specific intervention process. It is based on a comprehensive assessment of the student's aptitudes in all areas of development, for the purpose of verifying both qualitative and quantitative potentialities and limitations, where the latter are conceived as difficulties within a certain context rather than deficits that are linked to the individual (Acosta-Rodríguez \& MorenoSantana, 2003).

As for the timing of the intervention, as a general criterion, action is advised as soon as the disability becomes visible, or when there is a perceived possibility that it will appear. At that time systematic learning procedures should be established in the sphere of communication, whether linguistic and pre-linguistic (Acosta-Rodríguez \& Moreno-Santana, 
2003). Being aware of the correlation that exists between communication and cognitive or social-affective development, it is important to join forces not only to address therapy but also prevention. From this perspective, educational intervention is not just speech therapy to get the student to attain a certain linguistic behavior during the session; rather, its aim is for the student to be able to use and make use of language in different contexts and circumstances of life, whether at school, in the family or socially. The whole set of variables that make up the environment should be considered when planning the intervention (Acosta-Rodríguez, 2006b; Hemmeter \& Grisham-Brown, 1997).

If we take this multidimensional perspective as the most appropriate, it becomes essential that intervention in language and hearing be coordinated as closely as possible with general classroom work. The classroom is the context where pupils spend the most time and where they encounter the most meaningful messages and interlocutors in their world. It is fundamental to promote students' active participation and their natural, spontaneous involvement in the learning process, thereby making it more functional (Acosta-Rodríguez, 2003, 2004, 2005; Richards \& Rodgers, 1986).

This basis requires that language and hearing teachers have a solid founding in language development and communication, adequate training in school psychology, personal experience and work, awareness of their own possibilities and limitations, rigorous control over their professional practice, an inclusive attitude and assertiveness (Gallardo-Ruiz \& Gallego-Ortega, 1993). In addition to this method of classifying intervention models, based on a foundation in language development, we find other classifications that focus on the different organizational models of support that can be applied to the linguistic-communicative facet. Table 1 summarizes the main characteristics of such models.

Table 1.Organizational models of educational support (Adapted from Parrilla-Latas, 1996, p.83)

\begin{tabular}{cl}
\hline $\begin{array}{c}\text { MODELS OF } \\
\text { SUPPORT }\end{array}$ & CHARACTERISTICS \\
\hline & - "Child-centered support, guided and led by specialists or experts, based on the \\
Therapeutic & disabilities attributed to the child” (Parrilla-Latas, 1996, p.84) \\
Support & - The mainstream teacher's role is not active. The expert is in charge of support. \\
& - Work is done in the support classroom (a break for mainstream teachers?). \\
& - Individual support that focuses on each child's disabilities and intervenes with \\
& teaching that is appropriate to his or her needs (Muntaner-Guasp, 2000). \\
\hline Individual & - Care is no longer "expert" only, now incorporates the collaboration of the \\
Collaborative & referring party.
\end{tabular}




\begin{tabular}{|c|c|}
\hline $\begin{array}{c}\text { MODELS OF } \\
\text { SUPPORT }\end{array}$ & CHARACTERISTICS \\
\hline Support & $\begin{array}{l}\text { - In order to really take place, teacher roles must be redefined so as to promote } \\
\text { communication and their actual involvement. } \\
\text { - However, the student's disabilities continue to be addressed without questioning } \\
\text { the participation of the school or the contextual factors. }\end{array}$ \\
\hline $\begin{array}{l}\text { Support by } \\
\text { Consultation/ } \\
\text { Resources }\end{array}$ & $\begin{array}{l}\text { - Student needs are assumed to be related to contextual elements. } \\
\text { - The sphere of support action goes beyond social and school factors. } \\
\text { - However, the greatest weight is given to technical intervention or to some expert } \\
\text { who can be consulted for answers that the school may require. }\end{array}$ \\
\hline Curriculum support & $\begin{array}{l}\text { - Professional profiles are redefined (including those of the support teacher) by } \\
\text { working in "collaboration to solve problems related to the institution, the class } \\
\text { group or the individual" (Parrilla-Latas, 1996, p.106). } \\
\text { - The support targets not only the children but also the community as a whole, } \\
\text { always from a collaborative approach. } \\
\text { - There is the possibility for real integration of pupils with special educational } \\
\text { needs in the mainstream classroom, since there is a basis of cooperation among the } \\
\text { team of professionals in adapting a common curriculum. } \\
\text { - Support is conceived as preventive and developmental (not only corrective) and } \\
\text { diversity is valued as an enriching aspect for everyone. } \\
\text { - A "particular" educational culture is involved, since barriers to integration are } \\
\text { found in the persons themselves, in their head and in their heart. }\end{array}$ \\
\hline
\end{tabular}

In light of the intervention options explained above, we find it important that the language and hearing teacher be committed to comprehensive, collaborative action in line with the curriculum support model (team of professionals and family) and ecological models (acts of spontaneous, functional and generalizable communication in the different contexts and circumstances of school life, family life and social life). The importance of the school context must be assumed, and there must be a comprehensive approach to educational action in all matters. Thus, the course of action taken for attaining adequate linguistic development in these students is not the sole business of the language and hearing teacher, but should be shared by all the teachers at the school so as to make the most of occasions that arise in the class context, encouraging communication and interaction between the pupils and their classmates, thereby increasing their confidence and self-esteem (Moya-Maya, 2002).

If we revisit the national and international research that addresses this topic area, we find indications that adequate linguistic development in the classroom will only be achieved through a methodology that involves combined actions to address the different linguistic components, using collaborative strategies. The role of the language and hearing teacher in coordinating and advising the role of other educators is key to such strategies (AcostaRodríguez, 2004, 2005; Acosta-Rodríguez \& Moreno Santana, 1999, 2003). 
Regarding the first aspect, there are studies that emphasize the need to intervene in the set of factors that promote adequate language development as a whole, from the psychomotor, emotional, socio-affective and cognitive spheres (Fey, 1986; Fey, Catts \& Larrive, 1995). More detailed proposals should be put forward, including classroom methods that explicitly address the need to develop certain language prerequisites as curriculum content, and to develop the cognitive and socializing facet as part of the pursuit of language development. Pertinent contributions come from McCauley and Fey (2006), who, after more than 20 years of basic and applied research, propose a structural intervention model that incorporates certain novel aspects related to the frequency and intensity of working sessions, while also insisting on the importance of reevaluation of the intervention and subsequent program modification.

In these models, there would be a comprehensive approach to intervention within the classroom, occupied with meeting communication and language objectives. This approach does not rely so much on training in isolated skills, but it takes place within activities that are meaningful to the students, in the classroom routines and activities that students must engage in through use of language (Acosta Rodríguez, 2004, 2005; Acosta Rodríguez \& Moreno Santana, 1999, 2003). This contrasts with highly structured approaches that rely on procedures such as imitation, shaping, fading and generalization, and pursue objectives that mainly have to do with articulatory skills (Hodson \& Paden, 1991) or morpho-syntactic skills (Fey \& Cleave, 1997). A more global, interactive approach to language would focus on facilitating social communication by means of interactive modeling, appealing at times to conversations or narrations in order to achieve linguistic objectives (Brinton, Fujiki \& Powell, 1997), and always pursuing a collaborative perspective in conjunction with the team of teachers and family.

Other research studies ratify this perspective, advocating a curriculum approach that prioritizes the treatment of language and communication in a generalized sense across the student body. This action is characterized as dynamic, multidimensional and interactive, engaged in all components of language (Moreno Santana \& Leal Hernández, 2005), encompassing not only the corrective or rehabilitation facet, but also having a preventive and developmental nature. 
As for the collaborative role of parents and other teachers, there are studies that provide evidence of positive results from carrying out activities in the mainstream classroom and at home that are complementary to those done in the support classroom with the specialist, transferring the focus of the intervention directly to the child. In a meta-analysis from Law, Boyle, Harris, Harkness and Nye (2000), as many as 33 studies offer evidence for the effectiveness of this intervention modality in the expressive language of children, where priority is given to collaborative practices involving the family and teacher team, where early intervention supports and strengthens the whole context of the child's family and school, and active participation is solicited from these decision makers, through the implementation of individualized, differentiated proposals. One of the relevant programs that particularly stands out is the Hanen Program, created by Ayala Manolson (Manolson, 1992), and linked to a socio-interactionist perspective of language acquisition. The main objective is to explicitly instruct parents and teachers in a series of procedures designed to improve interaction situations with their children or pupils, offering a boost to communicative interaction.

\section{Objectives}

We want to inquire into the intervention methodologies and resources of the itinerant language and hearing teacher, the factors that affect intervention, the characteristics and models that are reflected. Specifically:

1. To learn whether the type of activities carried out involve preventive and developmental actions in addition to the traditional therapeutic work of speech therapists.

2. To analyze whether their work addresses the totality of linguistic components (phonetic, morpho-syntactic, semantic and pragmatic) from a collaborative dynamic, whether it is fully integrated into the curriculum, and if strengthens the socialization and educational aspect within the student body.

\section{Method}

\section{Participants}

In the research presented here, we try to analyze and understand the work of our target population, a group of itinerant language and hearing teachers (a professional profile exclusive to Spain). We will examine their educational practice, experiencing and perceiving its peculiarities, in order to meaningfully portray the set of dimensions that make up this 
natural reality. Nine primary education specialists in language and hearing were selected as informants; at the time of the investigation these nine teachers made up the totality of LH teachers assigned to the itinerant Educational Guidance Teams (hereafter, EGT) in Almeria province (Spain). See Tables 2 and 3.

Table 2. Number of contact sessions with each language and hearing teacher

\begin{tabular}{cccccccccc}
\hline LH & 1 & 2 & 3 & 4 & 5 & 6 & 7 & 8 & 9 \\
\hline $\mathrm{N}^{\circ}$ contacts & 6 & 5 & 5 & 5 & 5 & 5 & 6 & 4 & 5 \\
\hline
\end{tabular}

Table 3. Initials identifying each type of informant

\begin{tabular}{ccccccc}
\hline LH & CC & LL & M & G & TP & MT \\
\hline Elementary & Coordinator & Member of the & Mother & Guidance & Therapeutic & Mainstream \\
Language & of the & school's & & professional & Pedagogy & Teacher \\
and Hearing & Educational & leadership team & & & Teacher & \\
Teacher & $\begin{array}{c}\text { Guidance } \\
\text { Team }\end{array}$ & & & & & \\
& & & & & \\
\hline
\end{tabular}

\section{Instruments}

Instruments typical to qualitative methodology were used: in-depth interview (identified in the results section as I), field observation (identified in the results as FO) and document analysis (identified in the results as DA):

1) The in-depth interview was designed to be open, without a question guide as such. The interviews were held in a school immersion context, where the researchers were guided by the research objectives, giving priority to freely constructed discourse on the part of the interviewee, with minimal use of leading remarks from the interviewer that would encourage the appearance of relevant information.

2) Even more unstructured was the field observation, carried out from natural immersion in the language and hearing classrooms that were a part of this research. The observation role was expressly stated and communicated to the teachers. Any observed data that was pertinent to the objectives was afterward meticulously recorded in the field notebook.

3) Document analysis involved documents belonging to the language and hearing teachers and to the participating educational guidance teams, including planning and evaluation documents and school records. Documents were analyzed to obtain additional 
information, as well as for triangulation with the information gathered from interviews and observation.

\section{Procedure}

The procedure was based on multiple field immersion, with nine focal points, the contacts arranged through individual negotiations with each one. During the immersion, indepth interviews were alternated with spontaneous dialogues with different players, all of which was recorded in the field notebook, and documents were gathered for later analysis.

The nine focal points, consisting of the itinerant language and hearing teachers, were connected to seven different educational guidance teams for Almeria province (Spain). Each one was approached in an immersion context over a period of six weeks, in the form of weekly visits consisting of an entire school day. The months of September and October were excluded so that the the immersion would coincide with a period of regular LH activity, without the organizational uncertainties that often characterize itinerant functions at the beginning of the school year. This approach led to four immersion contexts: two contexts of the two EGTs that had two LH on staff, and two other contexts with two and three LH respectively, grouped according to geographic proximity, in order to facilitate the immersion process itself. This resulted in a total immersion period of 24 weeks, making it possible to finish before June, and thus avoid another period that generally has a higher number of organizational and curriculum issues.

As for the number of sessions, in several cases our process resulted in the full six contact sessions, another group had five sessions and in one case there were four sessions. In all cases the LH was approached in a personal, direct fashion, as was the school's leadership team in its coordination role, working within a multi-purpose collaboration framework that the research team has established with Almeria's provincial educational authority. After the immersion period, the information was processed, with an occasional visit held afterward to check data.

\section{Design and data analysis}

Several steps were followed in the analysis and interpretation of the qualitative data that informed our study (Goetz \& LeCompte, 1988; Rodríguez-Gómez, Gil-Flores \& García- 
Jiménez, 1996; Stake, 2007; Taylor \& Bogdan, 1986; Woods, 1989), coming from an ethnographic approach with multiple cases:
a) Gathering and transcribing the information.
b) Reducing and purging the information using the criteria of our research questions and objectives.
c) Precategorization and construction of interpretive text.
d) Simplification of the text and pre-categories.
e) Categorization and final report.

When processing the information, computer-based data processing was not considered relevant, since the information was gathered entirely in an immersion context, both the interview and the observation, and the researcher's own interpretive analysis was very important for getting the most value from the data. In fact, the category map that was generated is not based on a pre-categorical analysis, but rather on a constructive interpretation of the information, and from the set of didactic and linguistic elements that are ascertained from the state of the art (see Table 4):

Table 4. Categories

\begin{tabular}{cc}
\hline & CATEGORIES \\
\hline Didactic & Linguistic \\
\hline Methodology & Phonetic-phonological component \\
\hline Activities & Semantic component \\
\hline Mainstream involvement & Morphosyntactic component \\
\hline Timing & Pragmatic component \\
\hline Spatial organization & \\
\hline Material resources & \\
\hline
\end{tabular}

\section{Results}

\section{General traits of the LH teaching methodology}

The following represent the most important characteristics:

1) To our view, no defined model appears in the documents, instead, there are indications of the types of activities and resources that these professionals have been implementing (DA, LH7). ${ }^{1}$

\footnotetext{
${ }^{1}$ The direct quotes from qualitative empirical data are shown in the results section followed by two codes in parentheses, for example: (I, LH7). The first component of the pair represents the instrument from which the
} 
2) They use procedures and activities that fit their initially therapeutic effort to the educational purposes that anyone with a degree in Elementary Education has experienced from his or her teacher training (FO, LH5).

- "You can tell that she goes all out to maximize the benefit of her work, giving it as much educational value as possible” (I, LL).

3) Their action is usually motivating to the students and seeks to encourage their participation. As these professionals describe, they try to make the tasks enjoyable and they try to use material that is "quite varied and attractive to the kids. They [the pupils] come back happy and they like what they do there: games, worksheets, etc.”- (I, MT).

- "My methodology, well, I try for the children to have a good time when they are with me. In the first place I value them, I set some objectives and then I try to meet them in the most enjoyable way possible, for them and for me." (I, LH7)

4) They usually carry out activities with the students one on one or in pairs, and do not obtain sufficient support or coordination with the mainstream teacher on classroom tasks:

- "It's very important, but we would all need more time to coordinate, and honestly we are always pressed for time. I already mentioned that meetings are sporadic and we take advantage of recess periods. Besides, she does not have any specific hours assigned to the school for meetings, and she is the first one who is always in a hurry" (I, MT)

5) A certain differentiation with regard to these professionals' teaching methods can be established as a function of the linguistic component being developed. Their methodology varies - according to the linguistic component being worked on - between behavioral/formal language recovery and the development of a systematic awareness of its functions. There is no generalized, organized procedure of their own that guides their action; rather, self-

\footnotetext{
data was collected (I, FO or DA), and the second component represents the informant as codified in Table 3, with the added detail that in cases of LH teachers, a number from 1 to 9 is added in order to distinguish among them (Table 2).
} 
produced or commercially available materials are used as a function of the specific problem, frequency of treatment, and the idiosyncrasies of each professional (FO, LH3); (FO, LH5).

\section{Type of activities}

Whether the problems are phonetic-phonological, or have to do with the other linguistic components, a variety of linguistic activities are usually required (praxias, discrimination, articulation, memory, fluency, identification, etc.). In order to determine the precise activities needed, these professionals usually turn to the results of exploratory tests (FO, LH1). Test results are used both for guiding the type of activities to pursue (published materials or self-created) (DA, LH2), and for monitoring and evaluating achievement at the end of the school year (tracking sheet and final assessment).

\section{Phonetic-phonological component}

In the case of the phonetic-phonological component, the usual sequence of activities follows this order: development of prerequisites to production or shaping (breathing, blowing, logokinetics), exercises for positioning and for isolated or integrated production (repeated language modeled with decreasing use of aids such as tongue depressors, toothpicks, whistles, mirror, party blowers, etc.), promotion of directed language (with images) and spontaneous language (dialogues) (DA, LH8); (FO, AL9).

Most of the activities are based on games intended to keep the pupil's attention on tasks that are sometimes tedious, but are also, according to these professionals, "essential, such as lists of words that have to be practiced over and over" (I, LH4), breathing/blowing exercises, relaxation or praxias (very common in dyslalias), etc. (FO, LH7).

- “They shouldn't be monotonous or repetitive, since speech recovery is taxing and the exercises are tiresome for the young ones." (I, LL).

Generally speaking, work on the other components is characterized by a variety of activities based on the information supplied from speech evaluations and the problems recorded there. The professional seeks to solve these problems through practice or a set of specific actions that appear as one block in their planning documents (DA, LH3). 


\section{Semantic component}

Activities for working on the semantic component (referring to meaning) are based on games and software for word identification/fragmentation as well as vocabulary enrichment (DA, LH2).

\section{Morpho-syntactic component}

In order to work on the morpho-syntactic component (sentence formation), the LH teacher uses different activities where he or she seeks to reinforce the students' reading and writing processes, trying to correct their common errors in these instrumental skills. Typical writing errors are substituting one grapheme for another, inverting the order of syllables, rotation of letters, omissions, additions, word fragmentations, incorrect joining, and writing quality (size, handwriting, proper fitting to lined paper). Reading errors include mental blocks, repeating and backing up, phonological substitutions, lack of pacing, lack of comprehension, etc. (DA, LH3). These activities, given their wide-ranging nature and close connection with the work done in the mainstream classroom, "are usually carried out only as a supplement of autonomous work for the most advanced pupils" (I, LH5), being considered the domain of the Language Arts or support teacher, and not specific to the LH (FO, LH5).

\section{Pragmatic component}

Where there is a group need, the pragmatic component is addressed through activities that involve combined participation from the whole group. Periods of stimulating oral communication are geared toward enriching such communication in certain pupils that for different reasons (immaturity, lack of stimulation or other) present language that is very immature or not commensurate to their age (FO, LH3).

Activities for developing this component often consist of group dialogue and the expression of one's own experiences, taking advantage of small group settings so that the more inhibited child can communicate and also grow socially in this manner (FO, LH3). On other occasions, as required, stories are narrated, or even acted out with puppets, costumes or gestures, in order to work on time sequencing of events. Children are invited to narrate, describe, represent, etc. (FO, LH3). 


\section{Involvement of mainstream teachers}

There is little involvement of mainstream teachers in the activities that the language and hearing teachers are pursuing with their students. This leads to a rather individualistic effort on the part of the LH professionals in this study: Their work is planned and executed, in most cases, in complete independence from the other teachers that work with the student:

- "I am not familiar with her programming” (I, LL)

- "I feel that it is best to promote the direct action of these professionals, since we as classroom teachers have neither the time nor the preparation to address these problems (and at the same time we have other children who need our attention)" (I, MT).

If at some point they do enter the mainstream classroom or chat with the teachers, they try to act of models for behavior, and they offer some general guidelines, but they admit that there needs to be joint, ongoing action between the $\mathrm{LH}$, the mainstream teacher and family (FO, LH1). "There would have to be a system for coordination between everyone, something that does not exist. Really, if they are not here at the school we cannot ask for more. They are always on the run ...” (I, LL). Although infrequent, there are sometimes cases of teachers who show interest in facilitating the linguistic enrichment of the diagnosed students and of the class as a whole, although such initiatives tend to die off as the school year progresses (FO, MT).

The integration support teachers who work in the classroom may represent the other side of the coin in this aspect. They keep up a more ongoing collaboration and concur with the values of providing adequate attention to diversity in the educational setting (FO, LH9); (FO, TP):

"The only teachers with whom they have some ongoing collaboration are the Therapeutic Pedagogy professionals, but rarely with the regular classroom teacher." (I, TP)

\section{Timing}

Another aspect to discuss is the timing of activities. Some professionals comment that an improvised daily sequence of activities is the most appropriate, due to long periods of time between one session and the next, whether systematically established as such or due to student absenteeism (FO, LH8). 
As for distribution of hours, these professionals feel that insufficient time is allocated to the school overall in order to develop a comprehensive, collaborative, global educational function. Moreover, they feel that each diagnosed child should have "a minimum - as we have said many times in the meetings - of two thirty-minute sessions weekly for proper monitoring” (I, LH8), in order to accomplish the speech therapy goals that are being worked on, although this frequency is not always attained.

"Speech therapy requires more attention to the child, not just once every two weeks - except of course for justified absences - otherwise not much can be achieved. In addition we are only addressing a minimal number of the actual cases that need attention." (I, LL).

At present, with the limited hours that are assigned, it is impossible to carry out proper monitoring even from an individualistic approach, and the LHs collectively are calling for the establishment of a minimum required two weekly sessions so as to promote actual improvement.

"Right now, the time we have to work with the children, given the available resources, is very little. Speech therapy requires from two to three sessions per week. The thing is that right now, there is a large area with many schools, and more attention cannot be given." (I, LH5)

"More dedicated hours at the school in order to fulfill her function effectively. With the number of diagnosed children that there are, and the small amount of time that she is here each week, the speech therapy effort leaves much to be desired." (I, MT)

\section{Spatial organization}

1) Regarding spatial organization of where their activities take place, nearly all LHs consider that their intervention is mainly outside the regular classroom (FO, LH4), either individually with pupils or in small groups that have similar linguistic characteristics. (Students with special educational needs, from the specific classroom, always attend one at a time, since, according to the $\mathrm{LH}$, they require more continuous, individualized follow up.)

- "She takes the children to the library and works with them on their difficulties there.” (I, MT).

- "She takes my daughter to a little room next to the support classroom. She does the work herself ... taking the pupils one by one in order." (I, M). 
2) As for grouping, some indicate that at times they opt for small group work, in order to help meet the large demand, but at the same time they state that group work in speech therapy is not at all useful (FO, LH7).

"In order to be effective, treatment should be one-on-one, or at most with two at a time" (I, LH5).

Other professionals, however, recognize that working in the mainstream classroom would be very positive with its enhancement of the communication facet and social interaction with the natural group (FO, LH1). This type of work was reported in the Early Childhood classroom, in order to keep very small children from being separated from their class (FO, LH5).

3) Regarding the didactic use of classroom space, the following observations can be made regarding one session:

- Once the small working group is formed for the LH session, the pupils involved are subject to changeable grouping throughout the session, thereby providing the flexibility needed for proper treatment of the variability of needs among group members.

- Regarding the pupil's space in the classroom, the child has total autonomy to sit wherever he or she wishes, with no fixed or assigned space or desk. Thus, as a function of the activity to be performed (individual, with a partner, in the group), the child will occupy the place they want as long as it meets the proximity (for a joint or guided activity) or the distancing (to not get in each other's way) that is required (FO, LH8). Similarly, there are no requirements about remaining seated, the child may walk about the class as their interest is sparked by one activity or another, or as they need contact with the teacher (FO, LH9).

- Similarly, there is no established teacher's space in the classroom. Although she spends most of the session in front of the mirror with phono-articulatory shaping activities, she takes advantage of the beginning and end of the session to move to other classroom spaces that allow her to approach the group and promote spontaneous, global communication (table with chairs around, center of the classroom in U shape, etc.), (FO, LH2). 


\section{Material resources}

None of the professionals in this study considered material resources to be the main factor to be modified in order to improve their ongoing teaching function (FO, LH3).

When analyzing the materials these professionals use in the classroom, there are certain published programs that are used as a basis for developing the different linguistic components (DA, LH2). Sometimes, however, teacher-created materials are used to work on phonetic aspects (blowers, reeds, balloons) or semantic aspects (supermarket advertising brochures), requiring them to dedicate time to their design and preparation:

- "I'm aware that she comes with her car full of things that she herself creates and adapts.” (I, LL)

- "Actually, the materials are already prepared, with worksheets selected as a function of the phoneme that you are going to work on and its position within the word, or, if it is related to other components, the aspect we are going to cover in the session: activities, expression games, drawings that we use in representations of stories that work on vocabulary, and from there we do activities with naming, identification ... You give them the word and they identify, or they do the naming, eh?, etc. "(I, LH3)

These teachers are also regular users of new computer programs that are coming out, which they feel are beginning to address many relevant facets, "and are meeting with success.” (I, LH7); (FO, LH9).

- "I'm talking about computer programs that right now, I hardly have any that are on the market, but they are ones that I find from searching the Internet." (I, LH2).

Regarding this type of materials, some professionals comment on the scarcity of commercialized programs that promote non-phonetic components - such as the pragmatic or morpho-syntactic components - and the need for teachers to be more involved if they want their work to take on more of a global nature from the point of view of the pupil's linguistic development (FO, LH6).

- "I need more specific programs that are not on the market, since these are all focused on the phonetic aspect and phonology. So, there is a lack of a very important component which is the pragmatic component and the 
morphosyntactic component, which at the end of the day is what the children most need." (I, LH6).

Along these lines, we have begun to see demands across the entire educational system of the Knowledge Society for technology-based resources (audiovisual media, computers and software, etc.). The LH professional encounters the difficulty of being dependent on the location and availability of hardware at each school. In any case, these professionals directly participate in selecting the materials they use, and on many occasions they themselves are the authors, since they must adapt or invent material based on the specific needs of the students (FO, LH3); (FO, LH4); (DA, LH7).

"In many cases, we have to construct the materials we are going to use with our pupils, and try to adapt everyday items for the sake of cost savings and also because they are easy to acquire." (I, LH6)

\section{Discussion and Conclusion}

In the light of these results, we can state that the work of the language and hearing teacher, in the cases studied here, follows the approach of authors such as Acosta (2005) and Moreno and Leal (2005) in terms of promoting a multidimensional curriculum support modality; however, their approach is far from the collaborative, comprehensive approach defended by Hodson and Paden (1991) or Fey and Cleave (1997). A more global, interactive approach to language would be required from all those intervening in the pupil's educational process (the other teachers, family members), focusing on facilitating social communication across all contexts of action, along the lines proposed by Brinton, Fujiki and Powell (1997).

\section{Conclusions}

After analyzing the results from the different aspects examined by this investigation, we can state the following conclusions:

\section{Reproduction oriented intervention model}

The main thrust of activity focuses on reproductive-repetitive procedures dominated by the teacher's action. Content from the other areas is not addressed, nor is any activity assigned for the mainstream classroom (minimal collaboration at home and occasional collaboration with the therapeutic pedagogy professional). A similar sequence of activity types is observed in the different sessions and at the different schools (although this does not 
exclude improvisation in how they are carried out, or that something of creativity is fostered at the end of the sessions), but there is no detailed lesson planning that would form part of the curriculum. It was not possible to find evidence of any intervention with observable traits from the profile creation theoretical model, where priorities have to do with an advisory role and with non-therapeutic horizontal intervention.

\section{Methodology: activities and tasks}

Activities are done individually or in pairs, outside the regular classroom, without any attempt at collaborating with the rest of the teachers (except somewhat with the therapeutic pedagogy teacher) or with parents (who for the most part are not amenable). The approach is aimed exclusively at treating the specific problem (speech therapy) as diagnosed in the assessment report (pupils with special educational needs). The pressure of a traditional teaching environment overrules innovative principles in determining the tasks and activities that the itinerant language and hearing teacher executes with her students. Horizontal tasks with a collaborative nature scarcely appear on their control panel.

\section{Teaching and learning style}

The LH tries to consider each pupil's learning style and sources of motivation when setting activities to be followed (variety of materials, type of reinforcement/rewards, etc.). Their effort to make their work as didactic and educational as possible can be appreciated, within the constraints of their learning context and the task at hand. They follow an individualized sequencing of activities that follows the order of natural acquisition, according to the objectives that have been set, and fitting the strategies to the pupil's needs.

\section{Priority component: phono-articulatory}

The methodology focuses heavily on phono-articulatory, sequential interventions, although there is a broader range of content that is addressed in terms of typology and linguistic components.

\section{Insufficient human resources}

There is evidence of a scarcity of human resources for developing any of the intervention models that have been put forward. However, possibilities for a model that requires collaboration and non-teaching tasks are even more jeopardized. Time assigned to the school/educational community for tasks of planning/coordinating/attention, etc. was reported 
to be non-existent. This situation, combined with lack of interest from the families, and the school's conception of the external specialist, all complicate integration into the school community, as well as the effectiveness of their function.

Although demands focus on the quantity of resources, certain requirements as to the quality and type of action are beginning to be seen. This confirms that global/curriculum oriented action is becoming valued, as well as the demands and recognition that their itinerant work involves.

\section{Adequate material resources}

There is evidence of satisfaction with the available materials, although it was noted that the requirement of using one's own vehicle and the need to move materials from one place to another is a challenge to effective organization of resources in each school's dedicated space. We can further note that throughout this study, just as in research results from Fey (1986), there is a preeminence of clinical rehabilitation procedures that come from medicine and psychology, focused on performing assessments and successive interventions. While these help in overcoming certain problems - especial articulatory ones - they do not connect the linguistic skills taught with real communication or teaching-learning situations.

There is a need to encourage collaborative approaches where the different professionals who work with this type of student at school (language and hearing teacher and the remaining teachers in the mainstream or support classroom) will analyze his or her language in its production context and look for shared solutions, moving from an assessment model focused on the deficit to another more process-oriented model. This manner of working will make possible the necessary assistance for the child to use language in a global fashion, encouraging strategy use for accomplishing other classroom learning, in the line suggested by McCauley and Fey (2006).

Regarding the role of the family, we consider that this aspect also needs to be strengthened in order to ensure the effectiveness of this working model. Training and coordination with the family should be offered from the school, so that the family can become fully involved in the language assessment and intervention process, and classroom activities combined properly with activities the children do at home (see Turnbull, Turnbull \& Kyzar, 2009). 


\section{Future prospects}

It would be useful to continue in this direction and corrobate this analysis with multiple case studies in diverse educational contexts, enriching and delimiting what we have obtained here. Following are some possible ideas or channels of investigation that would be interesting to work on in the future, continuing to analyze professional thinking and the educational effort that these professionals are making, in order to further our knowledge of the educational possibilities in connection with this topic area.

a) What team teaching strategies can be developed at the schools such that the linguistic sphere is promoted, ensuring a multidisciplinary approach?

b) What action plans can be designed in order to incorporate attention to communication/linguistic diversity in the curriculum, and what role can the school LH play in implementing it?

\section{References}

Acosta-Rodríguez, V.M. (2003). Las prácticas educativas ante las dificultades del lenguaje. Una propuesta desde la acción. La colaboración entre logopedas, psicopedagogos, profesores y padres. [Educational practices for language impairments: A proposal from professional practice. Collaboration between speech therapists, school psychologists, teachers and parents.] Barcelona: Grupo Ars XXI de Comunicación, S.A.

Acosta-Rodríguez, V.M. (2004). Las prácticas educativas ante las dificultades del lenguaje. Una propuesta desde la acción. [Educational practices for language impairments: A proposal from professional practice.] Barcelona: STM Editores.

Acosta-Rodríguez, V.M. (2005). Evaluación, intervención e investigación en las dificultades del lenguaje en contextos inclusivos. Revisión, resultados y propuestas. [Assessment, intervention and research in language impairments in inclusive contexts.] Revista de Logopedia, Foniatría y Audiología, 25(4), 148-161. http://dx.doi.org/10.1016/S02144603(05)75833-2

Acosta-Rodríguez, V.M. (2006a). Efectos de la intervención y el apoyo mediante prácticas colaborativas sobre el lenguaje del alumnado con necesidades educativas específicas. [Effects of intervention and support through collaborative practices on language in students with specific educational needs.] Revista de Logopedia, Foniatría y Audiología, 26(1), 36-53. http://dx.doi.org/10.1016/S0214-4603(06)70095-X 
Acosta-Rodríguez, V.M. (2006b). El papel del lenguaje en la escolarización de todo el alumnado: revisión, desafíos y propuestas. [The role of language in the school of all pupils: review, challenges and proposals.] In E. Mendoza Lara (Ed.), Actas XXV Congreso Internacional de AELFA (pp.53-65). Granada: Universidad de Granada.

Acosta-Rodríguez, V.M. \& Moreno-Santana, A. M. (1999). Dificultades del lenguaje en ambientes educativos. Del retraso al trastorno específico del lenguaje. [Language impairments in educational settings: from retardation to the specific language impairment.] Barcelona: Masson.

Acosta-Rodríguez, V.M. \& Moreno Santana, A. M. (2003). Dificultades del lenguaje: una perspectiva educativa. [Language impairments: an educational perspective.] Bordón, 55(1), 51-60.

Bloom, L. \& Lahey, M. (1978). Language development and language disorders. New York: Wiley \& Sons.

Brinton, B., Fujiki, M., \& Powell, J. (1997). The ability of children with language impairment to manipulate topic in a structured task. Language, Speech and Hearing Services in Schools, 28, 3-11.

Castejón-Fernández, L.A. \& España-Ganzaráin, Y. (2004). La colaboración logopedamaestro: hacia un modelo inclusivo de intervención en las dificultades del lenguaje. [Speech therapist-Teacher collaboration: towards an inclusive intervention model in language impairments.] Revista de Logopedia, Foniatría y Audiología, 24, 55-66. http://dx.doi.org/10.1016/S0214-4603(04)75781-2

Cooper, J., Moodley, M. \& Reynell, J. (1982). Método para favorecer el desarrollo del lenguaje. Un programa de desarrollo para los niños con una problemática del lenguaje en edades tempranas. [A method to encourage language development: a development program for children with language problems at an early age.] Barcelona: Médica y Técnica.

Crystal, D. (1981). Lenguaje infantil, aprendizaje y lingüística. [Children's language, learning and linguistics.] Barcelona: Médica y Técnica.

Dubois, M. E. (1991). El proceso de lectura: de la teoría a la práctica. [The reading process: from theory to practice.] Buenos Aires: Aique.

Fey, M. (1986). Language intervention with young children. Needham Heights, MA: Allyn \& Bacon.

Fey, M., Catts, H. \& Larrive, L. (1995). Preparing preschoolers for the academic and social challenges of school. In S. Warren \& J. Reichle (Eds.), Communication and language intervention series, vol. 5, Language intervention: Preschool through the elementary years (pp. 3-37). Baltimore: Paul H. Brookes P. 
Fey, M., \& Cleave, P. (1997). Two models of grammar facilitation in children with language impairments. Journal of Speech. Language, and Hearing Research, 40, 5-19.

Gallardo-Ruiz, J.R. \& Gallego-Ortega, J.L. (1993). La intervención del lenguaje [Intervention in language]. In J.R. Gallardo Ruiz \& J.L. Gallego Ortega (Eds.), Manual de Logopedia Escolar. Un enfoque práctico. Málaga: Ediciones Aljibe.

Goetz, J.P. \& Le Compte, M.D. (1988). Etnografía y diseño cualitativo en investigación educativa. [Ethnography and qualitative design in educational research.] Madrid: Morata.

Hemmeter, M. \& Grisham-Brown, J. (1997). Developing children's language skills in inclusive early childhood classrooms. Dimensions of Early Childhood, 25, 6-13.

Hodson, B., \& Paden, E. (1991). Targeting intelligible speech: A phonological approach to remediation. Austin, TX: PRO-ED.

Law, J., Boyle, J., Harris, F., Harkness, A., \& Nye, C. (2000). The relationship between the natural history and prevalence of primary speech and language delays: Findings from a systematic review of the literature. International Journal of Language and Communication Disorders, 35, 165-188. http://dx.doi.org/10.1080/136828200247133

Leal Hernández, E. \& Moreno Santana, A.M. (2005). Estudio de las prácticas educativas con niños con trastorno específico del lenguaje. [A study on educational practices with children with specific language disorders.] Revista de logopedia, foniatría y audiología (4)25, 174-189. http://dx.doi.org/10.1016/S0214-4603(05)75835-6

Lindsay, G. \& Dockrell, J. (2002). Meeting the needs of children with speech, language and communication needs: a critical perspective on inclusion and collaboration. Child Language Teaching and Therapy, 18, 91-101.

http://dx.doi.org/10.1191/0265659002ct229ed

Manolson, A. (1992). It takes two to talk. Toronto: The Hanen Centre.

McCauley, R., \& Fey, M. (2006). Treatment of language disorders in children. Baltimore: Paul. H. Brookes P.

Monfort, M. (1983). La intervención logopédica. [Speech therapy intervention.] Cuadernos de pedagogía, 101, 20-26.

Monfort, M. (1990). Logopedia. [Speech therapy] Cuadernos de pedagogía, 178, 84-86.

Moya-Maya, A. (2002). El profesorado de apoyo ¿dónde? ¿cómo? ¿cuándo?... realiza su trabajo. [Support teachers: where? how? when? ... are they to carry out their work.] Málaga: Ediciones Aljibe.

Muntaner-Guasp, J.J. (2000). Aportaciones de la Educación Especial a las escuelas eficaces. [Contributions from Special Education to effective schools.] In A. Miñambres-Abad \& G. Jové-Monclús (Eds.), La atención a las necesidades educativas especiales: De la 
educación infantil a la universidad (pp.77-93). Lleida: Ediciones de la Universidad de Lleida.

Parrilla-Latas, A. (1996). Apoyo a la escuela: un proceso de colaboración. [Support for the school: a collaboration process.] Bilbao: Mensajero.

Prelock, P. (2000). An intervention focus for inclusionary practice. Language, Speech \& Hearing Services in Schools, 31, 296-298.

Richards, J.C. \& Rodgers, T.S. (1986). Approaches and methods in language teaching: A description and analysis. Cambridge: Cambridge University Press.

Rodríguez-Gómez, G., Gil-Flores, J. \& García-Jiménez, E. (1996). Metodología de la Investigación Cualitativa. [Qualitative research methodology.] Málaga: Ediciones Aljibe.

Stake, R.E. (2007). Investigación con estudio de casos. [Research with case studies.] Madrid: Morata.

Taylor, S.J. \& Bogdan, R. (1986). Introducción a los métodos cualitativos de investigación. [Introduction to qualitative research methods.] Barcelona: Paidós.

Turnbull, A., Turnbull, H. \& Kyzar, K. (2009). Cooperación entre familias y profesionales como fuerza catalizadora para una óptima inclusión: enfoque de los Estados Unidos de América. [Cooperation between families and professionals as a catalyzing force for optimal inclusión: an approach from the USA.] Revista de Educación, 349, 69-99. DOI: 10-4438/1988-592X-RE-2012-363-175.

Vigotsky, L. (1995). Pensamiento y lenguaje. [Thought and language] Buenos Aires: Paidós

Wiig, E. H., (2001). Valoración del lenguaje basada en la actuación del alumno en los colegios. Introducción de nuevas herramientas para la observación del comportamiento y planificación de la intervención. [Language assessment based on the pupil's performance at school. Introducing new tools for observing behavior and planning the intervention.] Revista de Logopedia, Foniatría y Audiología, 21, 24-30. http://dx.doi.org/10.1016/S0214-4603(01)76180-3

Woods, P. (1989). La escuela por dentro: la etnografía en la investigación educativa. [The school inside: ethnography in educational research.] Barcelona: Paidós. 